\title{
Enumeration and Characterization of Mesenchymal Stem Cells from Age- dependent Human Dental Tissue
}

\author{
Neetu Singh ${ }^{1 *}$, Umesh Pratap Verma ${ }^{2}$, Rebecca Chowdhury ${ }^{2}$, Archana Mishra ${ }^{3}$, Dinesh Kumar Sahu ${ }^{4}$, Ashutosh Shrivastava ${ }^{1}$, Nandlal ${ }^{2}$ and
} Ravi Kant ${ }^{5}$

${ }^{1}$ Department of Molecular Biology, Center for Advance Research, King George's Medical University, Lucknow-226 003, India

${ }^{2}$ Department of Periodontics, King George's Medical University, Lucknow-226 003, India

${ }^{3}$ Department of Biochemistry, King George's Medical University, Lucknow-226 003, India

${ }^{4}$ Imperial Life Sciences, 463 Phase City 2nd, Sector 37, Gurgaon, Haryana-122001, India

${ }^{5}$ Department of Surgical Oncology, King George's Medical University, Lucknow, Uttar Pradesh-226 003, India

\begin{abstract}
Age-dependent chronic and aggressive periodontitis patients need renewal of soft and hard tissue like periodontal ligament, gingiva, cementum and alveolar bone. Hence, multipotent-Mesenchymal Stromal Cells (MSCs) of different dental origin like Dental Pulp (DP); Periodontal Ligament (PDL); Gingiva; Apical Papilla (AP) may play important role in regeneration of periodontal tissue. For the accomplishment of this objective, we standardized and validated the manufacturing process of dental-MSCs sources like DP, PDL, AP and gingiva from the subjects ranging from the age of 13 to 60 years. As per, International guidelines, we isolated and enumerated plastic-adherent MSCs at different time-points from different dental sources, phenotypically characterized these cells and differentiated them into osteogenic, adipogenic, and chondrogenic cells. Importantly, in subjects from 13-31 years copious DP gave an appropriate amount of MSCs. While, between the age group 50-60 years negligible amount of DP was extracted, which did not provide any MSCs. However, PDL and gingiva produced a good amount of MSCs from 13-31 years, but in 50-60 years the yield was not good. Hence, age does affect MSCs number which is the reason of delayed healing in older age group subjects compared to younger subjects.
\end{abstract}

Keywords: Periodontitis; Mesenchymal stromal cells; Dental pulp; Periodontal ligament; Gingiva; Apical papilla

\section{Introduction}

Mesenchymal stromal cells (MSCs) of dental origin can be derived from various tissue sources like Dental pulp (DP) involved in formation of dentin and bone-like structure; stromal cells from human exfoliated deciduous teeth (SHEDs) helps in eruption of permanent tooth and secretes neurotrophic factors to improve craniofacial defects/tooth loss/bone regeneration; Periodontal ligament (PDL) stromal cells helps in the formation of periodontal structures like cementum and periodontal ligament and alveolar bone; dental follicle progenitor stromal cells which help in the genesis of permanent tooth; stromal cells from apical papilla (AP) which differentiates in odontoblasts/ osteoblasts [1,2]. The role of MSCs in periodontitis has also been explored through various reports [3-5]. Specifically, in the older age group-chronic [6] and younger age group-aggressive periodontitis [7] (CP and AP respectively) patients need regeneration of soft and hard tissue like periodontal ligament, gingiva, cementum and alveolar bone. Hence, multipotent-MSCs would may play important role in regeneration of periodontal tissue. To accomplish this objective, we standardized and validated the manufacturing process of dental-MSCs sources like DPSCs, PDLSCs, SCAPs and gingival fibroblasts (GFs) from the subjects ranging from the age of 13 to 60 years.

\section{Materials and Methods}

Impacted/Non-Impacted third molar and orthodontically sacrificed tooth were collected and transported in Hank balanced salt solution from the Department of Periodontology, KGMU to Center for Advance Research (CFAR) and was considered for this study. The study has been ethically approved by the Institutional Ethical Committee. The written consent was obtained from patients for the orthodontically sacrificed-, impacted-, non-impacted-, artificial denture-tooth extraction and isolation of Dental pulp/periodontal ligament/gingiva/ apical papilla.

\section{Isolation of dental tissue}

From each tooth, firstly, gingiva was extracted from periodontium and collected in chilled sterile PBS; PDL tissue around the cementenamel junction (CEJ) was scrapped with a scalpel blade in chilled sterile PBS; for DP, tooth was split vertically into two equal halves using a diamond carbide bur in chilled PBS using a rotatory motor with minimum speed and copious irrigation of chilled sterile PBS (Figure 1a). DP tissue was pulled out using Curettes or endodontic file, and extracted DP was transferred in sterile chilled PBS (Figure 1b). AP, loosely attached to the apex of the developing root was easily detachable (Figure 2).

\section{Dental tissue processing for cell culture}

All the samples were processed in the GMP-compliant facility in a Class II microbiological safety cabinet. All the extracted and decontaminated tissues were cut into small pieces and digested in an enzymatic solution for $30 \mathrm{~min}$ at $37^{\circ} \mathrm{C}$ containing collagenase 1 ( $3 \mathrm{mg} / \mathrm{ml}$ ) and $4 \mathrm{mg} / \mathrm{ml}$ dispase to liberate the cells. After complete digestion the enzyme was neutralized by adding medium. The obtained suspension was centrifuged and the pellet was mixed with the medium

*Corresponding author: Neetu Singh, Ph.D., Department of Molecular Biology Center for Advanced Research KGMU, Lucknow, Uttar Pradesh, 226 003, India, Tel: +91-9984801444; E-mail: neetuaashi@yahoo.com

Received August 05, 2016; Accepted September 02, 2016; Published September 09, 2016

Citation: Singh N, Verma UP, Chowdhury R, Mishra A, Sahu DK, et al. (2016) Enumeration and Characterization of Mesenchymal Stem Cells from Agedependent Human Dental Tissue. J Stem Cell Res Ther 6: 359. doi: 10.4172/21577633.1000359

Copyright: ( 2016 Singh N, et al. This is an open-access article distributed under the terms of the Creative Commons Attribution License, which permits unrestricted use, distribution, and reproduction in any medium, provided the original author and source are credited. 
Citation: Singh N, Verma UP, Chowdhury R, Mishra A, Sahu DK, et al. (2016) Enumeration and Characterization of Mesenchymal Stem Cells from Age-dependent Human Dental Tissue. J Stem Cell Res Ther 6: 359. doi: 10.4172/2157-7633.1000359

Page 2 of 5
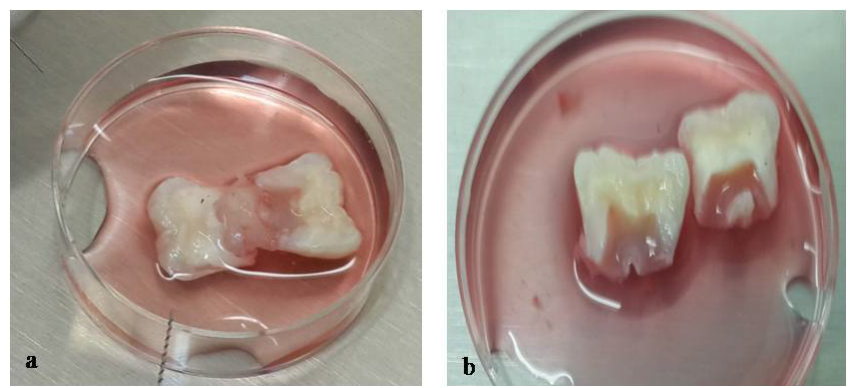

Figure 1: (a) Dental pulp of 13 year subject's tooth after vertical split of tooth into two equal halves using a diamond carbide bur in chilled PBS using a rotatory motor with minimum speed and copious irrigation of chilled sterile PBS (b) After pulling out DP tissue using curettes or endodontic file, hollow DP cavity.

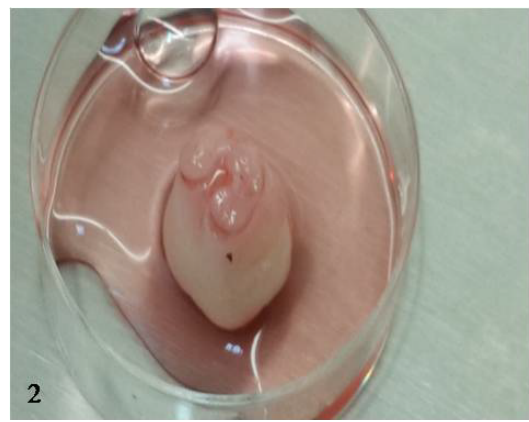

Figure 2: Apical Papilla (AP), loosely attached to the apex of the developing root of 16 years old subject.

(DMEM low glucose $(1 \mathrm{~g} / \mathrm{L})$ supplemented with $10 \%$ FBS, Penicillin $(10 \mathrm{mg} / 100 \mathrm{ml})$, Streptomycin $(20 \mathrm{mg} / 100 \mathrm{ml})$, L-glutamine $(10$ $\mathrm{mg} / 100 \mathrm{ml}$ ) and incubated at $37^{\circ} \mathrm{C}$ in a humidified atmosphere with $5 \% \mathrm{CO}_{2}$ ) and were transferred to T-25 flask (Figure 3). The T-25 flasks were left undisturbed in a $5 \% \mathrm{CO}^{2}$ incubator maintained at $37^{\circ} \mathrm{C}$ for $4-5$ days after which fresh culture medium was supplemented. Adherent cells were allowed to expand for 10-15 days by changing the media at an interval of 2 days. A cell count and viability check were performed after harvesting the cells, and about a million cells were re-plated into $300 \mathrm{~cm}^{2}$ tissue culture flasks for further expansion.

\section{Phenotypic characterization}

$1 \times 10^{6}$ cells from second or third passage were subjected to immune-phenotypic analysis. Cultured cells were washed in staining buffer (PBS+2\% FCS) and centrifuged at $300 \times \mathrm{g}$, for $5 \mathrm{~min}$ at $40^{\circ} \mathrm{C}$. The supernatant was discarded and resuspended to $\sim 10^{6}$ cells/tube with staining buffer with $500 \mu \mathrm{l}$ incubated with various mouse anti-human antibodies/Propidium Iodide/Isotype controls. Briefly, one tube consisted of combined staining of CD73APC/CD90FITC/CD105PE/ CD34PECy7/CD20PECy7/CD45PECy7/CD14PECy7; second tube was prepared for unstained cells (with PI staining only); third tube was prepared for Isotype controls (Isotype APC/Isotype FITC/Isotype PE/ Isotype PECy7). Simultaneously, separate compensation tubes $\left(5 \times 10^{5}\right)$ were prepared for CD73APC, CD90FITC, CD105PE, CD73PECy7. All the tubes with antibodies were incubated at $40^{\circ} \mathrm{C}$ in the dark for 30 mins. $1 \mathrm{ml}$ staining buffer was added and the tubes were vortexed and centrifuged. The supernatant was discarded and was resuspended in $200 \mu \mathrm{l}$ staining buffer/tube. $5 \mu \mathrm{l}$ PI was added to each tube and the cells were acquired through Amnis-Image based Flow Cytometer. Firstly, we acquired data for unstained cells, drew gate to singlet's based on Area_M01 versus Aspect Ratio_M01 and subgate for non-PI positive events. The template was saved for further evaluation. Raw Max Pixel Graphs were drawn for Ch2 (FITC), Ch3 (PE), Ch4 (PI), Ch5 (APC) and Ch6 (PECy7) and laser powers were adjusted for 488 and $642 \mathrm{~nm}$ lasers respectively. Approximately 10,000 events were acquired and data analysis was performed using the IDEAS-Image Stream analysis Software.

\section{Functional differentiation studies}

To induce osteogenic, adipogenic and chondrogenic differentiation, second-to-third passage cells $\left(0.1 \times 10^{6}\right.$ cells $)$ respectively, were plated and cultured for $48 \mathrm{~h}$ to reach the confluence $70 \%$. Further, these cells were supplemented with osteogenic, adipogenic and chondrogenic medium for three weeks with medium changes twice weekly. Osteogenesis, adipogenesis and chondriogenesis were assessed at weekly intervals.

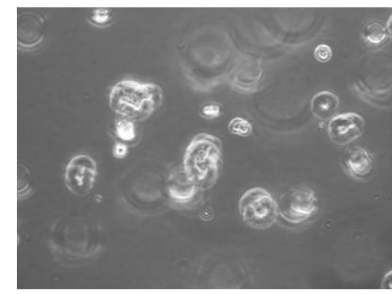

Single Cell Suspension-Day 0

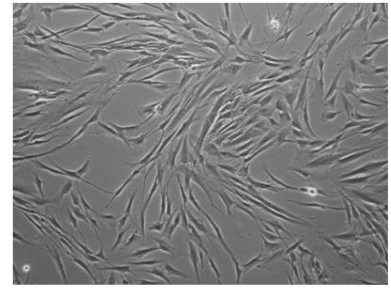

Dental Pulp-Day 15

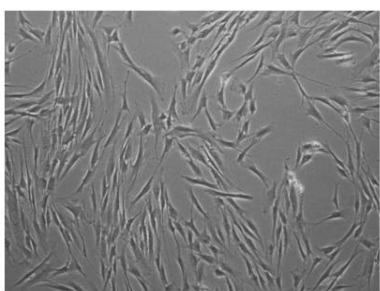

PeriodontalLigament-Day 15

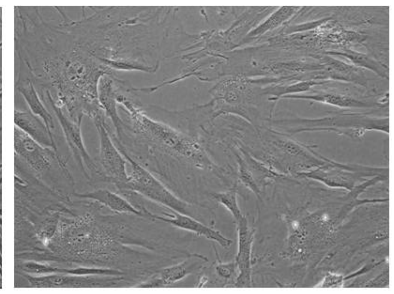

Apical Papilla-Day 15

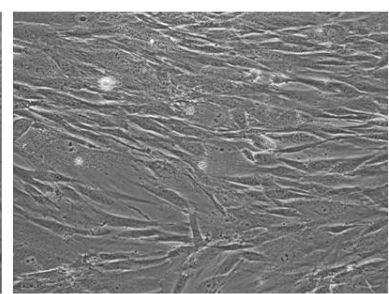

Gingival tissue-Day 15

Figure 3: Single suspension from dental pulp tissue at day 0 and fibroblastic appearance of cells at day 15 from various different sources. 


\section{Adipogenic differentiation}

To induce adipogenic differentiation, second-to-third passage cells were treated with both commercial as well as In-house adipogenic medium for three weeks. Medium changes were carried out twice weekly and adipogenesis was assessed at third week. In-house adipogenic medium consists of DMEM supplemented with $0.5 \mathrm{mM}$ 3-isobutyl-1-methylxanthine (Sigma), $1 \mu \mathrm{M}$ dexamethasone (Sigma), $0.1 \mathrm{mM}$ indomethacin (INDO, Sigma), $10 \mu \mathrm{g} / \mathrm{ml}$ insulin, and $20 \%$ FBS (Gibco). Adipocyte differentiation was demonstrated by staining with $0.5 \% \mathrm{w} / \mathrm{v}$ Oil Red O-stock solution in Isopropanol. PBS washed cells were fixed in pre-cool methanol at $-200^{\circ} \mathrm{C}$ for $5 \mathrm{~min}$ at room temperature. Methanol was aspirated and the cells were washed with $2 \mathrm{ml}$ deionized water and the cells were stained with $2 \mathrm{ml}$ Oil Red O for $20 \mathrm{~min}$ at plate shaker at room temperature. Finally, the dye was aspirated and washed with deionized water and imaged with a Nikon fluorescence microscope.

\section{Osteogenic differentiation}

To induce osteogenic differentiation, the second-to-third passage cells were treated with osteogenic medium (commercially supplied as well as in-house prepared) for three weeks with medium changes twice weekly. Osteogenesis was assessed after the third week. In-house osteogenic medium consisted of DMEM supplemented with $0.1 \mu \mathrm{M}$ dexamethasone (Sigma, St. Louis, MO, USA), 2 mM L-glutamine, $10 \%$ FBS, $10 \mathrm{mM} \beta$-glycerol phosphate (Sigma) and $0.2 \mathrm{mM}$ ascorbic acid (Sigma). Differentiation to osteoblasts was demonstrated by staining with BCIP/NBT. PBS washed cells were fixed in pre-cool methanol at $-200^{\circ} \mathrm{C}$ for $5 \mathrm{~min}$ at room temperature. Methanol was aspirated and the cells were washed with $2 \mathrm{ml}$ deionized water and the cells were stained with BCIP/NBT tablets (solubilised in 10ml water) for $20 \mathrm{~min}$ at plate shaker at room temperature. Finally, the dye was aspirated and washed with deionized water and imaged with a Nikon fluorescence microscope (The Eclipse).

\section{Chondrogenic differentiation}

To induce chondrogenic differentiation, second-to-third passage cells were treated with chondrogenic medium (MACS-Miltenyi Biotech) for three weeks. Medium changes were carried out twice weekly and chondriogenesis was assessed at third week. Chondrogenic medium consists of DMEM supplemented with $10 \mathrm{ng} / \mathrm{ml}$ TGF- $B 3$ (transforming growth factor B3), $10 \mathrm{ng} / \mathrm{ml} \mathrm{BMP6} \mathrm{(bone} \mathrm{morphogenetic}$ protein-6), $50 \mathrm{mg} / \mathrm{ml}$ insulin transferin selenium+premix, $1.25 \mathrm{mg}$ bovine serum albumin and $1 \%$ fetal bovine serum. Chondroblasts were observed as knob like structure.

\section{Results}

After fulfilling the basic criteria as suggested by International Guidelines, we isolated and enumerated MSCs at different time-points from different dental sources using commercial and in-house media (Figure 3) which were plastic-adherent in standard culture conditions (Table 1) and were grown in T-25 flasks. The flasks were maintained in triplicates and the cells were counted through trypan blue method. Phenotypically these cells were expressed as CD105, CD73 and CD90, and lacked expressions of CD45, CD34, CD14, and CD20 [8,9] (Figure 4). In addition, MSCs of different passages differentiated into adipogenic (second-to-third passage), osteogenic (second-to-third passage) and chondrogenic (second-to-third passage) cells (Figures 5a-5c). Importantly, in subjects from 13-31 years, DP was isolated in appropriate amount through which good number of MSCs was grown. Although, between the age group 50-60 years very less amount of DP and no MSCs were identified on day 14. In case of PDL and the gingiva appropriate amount of MSCs were isolated from 13-31 years, but in 50-60 years the yield was not good.

\section{Discussion}

As reported previously, age-dependent narrowing of the pulp canal results in calcification of DP tissue [10]. In the age group of 50-60 years, we also observed very low amount of DP and MSCs. However, in patients from 13-31 years, DP was isolated in appropriate amount through which good amount of MSCs was grown.

In developing tooth bud, the AP towards maturity converts into root cementum attachment of periodontal ligament fibers and mature tooth [11]. Specifically for third molar these squeal of events ranges from the age of 17-21 years [11]. Hence, we observed AP in third molar of the subject of age group 16 years through which appropriate amount of MSCs was derived. However, in patients ranging from 30-60 years, we were not able to get $\mathrm{AP}$, this may owe to the conversion of $\mathrm{AP}$ into mature tooth. Importantly, in 13 year subject the premolars AP

\begin{tabular}{|c|c|c|c|c|c|}
\hline \multirow[b]{2}{*}{ S. No. } & \multirow[b]{2}{*}{ Age and details of patients } & \multicolumn{4}{|c|}{ Isolation of MSCs from different type of dental-tissues } \\
\hline & & Dental Pulp (10-12 mg) & $\begin{array}{l}\text { Periodontal Ligament } \\
(1-2 \mathrm{mg})\end{array}$ & Gingiva (2-5 mg) & $\begin{array}{l}\text { Apical Papilla } \\
(10-12 \mathrm{mg})\end{array}$ \\
\hline 1. & $\begin{array}{l}13 \text { years (Female) -Treatment of choice-Orthodontically sacrificed-I } \\
\text { premolar (for proper alignment and to create space to move the } \\
\text { anterior teeth into their proper position) }\end{array}$ & $\begin{array}{l}1.0 \times 10^{6}-1.8 \times 10^{6} \\
\left( \pm 0.404 \times 10^{6}\right)\end{array}$ & $\begin{array}{l}1.0 \times 10^{6}-1.8 \times 10^{6} \\
\left( \pm 0.404 \times 10^{6}\right)\end{array}$ & $\begin{array}{l}1-8 \times 10^{6}-2.0 \times 10^{6} \\
\left( \pm 0.1 \times 10^{6}\right)\end{array}$ & - \\
\hline 2. & $\begin{array}{l}16 \text { years (Female) - Treatment of choice-Impacted third molar- } \\
\text { extraction \{Patient was diagnosed pericoronitis (inadequate space } \\
\text { between distal to second molar and impacted third molar)\} }\end{array}$ & $\begin{array}{l}1.0 \times 10^{6}-1.8 \times 10^{6} \\
\left( \pm 0.416 \times 10^{6}\right)\end{array}$ & $\begin{array}{l}1.0 \times 10^{6}-1.8 \times 10^{6}( \pm \\
\left.0.404 \times 10^{6}\right)\end{array}$ & $\begin{array}{l}1-8 \times 10^{6}-2.0 \times 10^{6} \\
\left( \pm 0.152 \times 10^{6}\right)\end{array}$ & $\begin{array}{l}1.8 \times 10^{6}-2.1 \times 10^{6} \\
\left( \pm 0.15 \times 10^{6}\right)\end{array}$ \\
\hline 3. & $\begin{array}{l}31 \text { years (Female) -Treatment of choice-Impacted Third Molar } \\
\text { extraction (patient was suffering from pericoronitis) }\end{array}$ & $\begin{array}{l}0.5 \times 10^{6}-0.9 \times 10^{6} \\
\left( \pm 0.2 \times 10^{6}\right)\end{array}$ & $\begin{array}{l}0.8 \times 10^{6}-0.9 \times 10^{6} \\
\left( \pm 0.055 \times 10^{6}\right)\end{array}$ & $\begin{array}{l}0.9 \times 10^{6}-1.0 \times 10^{6} \\
\left( \pm 0.055 \times 10^{6}\right)\end{array}$ & - \\
\hline 4. & $\begin{array}{l}30 \text { years (Male)-Treatment of choice-Impacted Third Molar extraction } \\
\text { (patient was suffering from pericoronitis) }\end{array}$ & $\begin{array}{l}0.5 \times 10^{6}-0.9 \times 10^{6} \\
\left( \pm 0.152 \times 10^{6}\right)\end{array}$ & $\begin{array}{l}0.9 \times 10^{6}-1.0 \times 10^{6}( \pm \\
\left.0.055 \times 10^{6}\right)\end{array}$ & $\begin{array}{l}0.9 \times 10^{6}-1.2 \times 10^{6} \\
\left( \pm 0.152 \times 10^{6}\right)\end{array}$ & - \\
\hline 5. & $\begin{array}{l}52 \text { years (Male)-Treatment of choice-Impacted Third Molar extraction } \\
\text { (the antagonist tooth was missing because of which the third molar } \\
\text { had lost it's attachment) }\end{array}$ & Very low amount of DP & $1 \mathrm{mg}$ & $1 \mathrm{mg}$ & - \\
\hline 6. & $\begin{array}{l}55 \text { years (Female) -Treatment of choice-Impacted Third Molar } \\
\text { extraction (patient was willing for artificial tooth hence, } 7-8 \text { tooth } \\
\text { including incisor, canine, pre-molars and molars were extracted) }\end{array}$ & Very low amount of DP & $1 \mathrm{mg}$ & $1 \mathrm{mg}$ & - \\
\hline 7. & $\begin{array}{l}60 \text { year (Male)-Treatment of choice-Impacted Third Molar extraction } \\
\text { (the antagonist tooth was missing and was creating periodontal } \\
\text { problems like trauma to the adjacent tissue) }\end{array}$ & Very low amount of DP & $1 \mathrm{mg}$ & $1 \mathrm{mg}$ & - \\
\hline
\end{tabular}

Table 1: Enumeration of Mesenchymal Stem Cells from various human dental tissue from patients of different age groups. 
Citation: Singh N, Verma UP, Chowdhury R, Mishra A, Sahu DK, et al. (2016) Enumeration and Characterization of Mesenchymal Stem Cells from Age-dependent Human Dental Tissue. J Stem Cell Res Ther 6: 359. doi: 10.4172/2157-7633.1000359

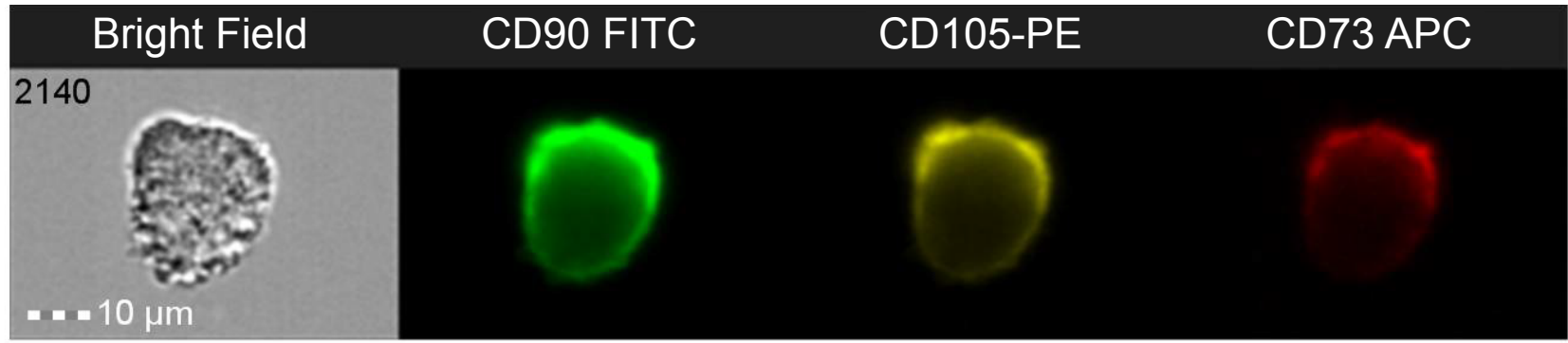

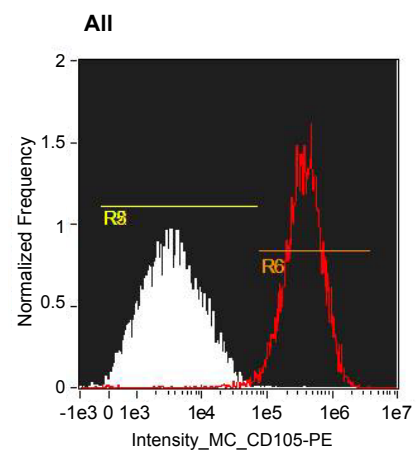

Intensity_MC_CD105-PE

\begin{tabular}{|l|l|l|l|}
\hline Population & Count & \%Gated & Median \\
\hline All & 10000 & 100 & 374815.76 \\
\hline R5 & 186 & 1.86 & 49419.48 \\
\hline R6 & 9813 & 98.1 & 380903.65 \\
\hline
\end{tabular}

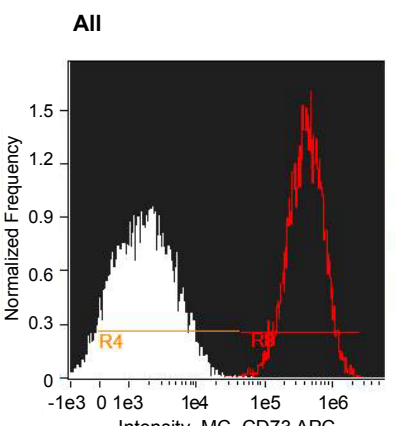

Intensity_MC_CD73 APC

Intensity_MC_CD73 APC

\begin{tabular}{|l|l|l|l|}
\hline Population & Count & \%Gated & Median \\
\hline All & 10000 & 100 & 120636.8 \\
\hline R7 & 35 & 0.35 & 5103.48 \\
\hline R8 & 9955 & 99.6 & 121130.5 \\
\hline
\end{tabular}

All

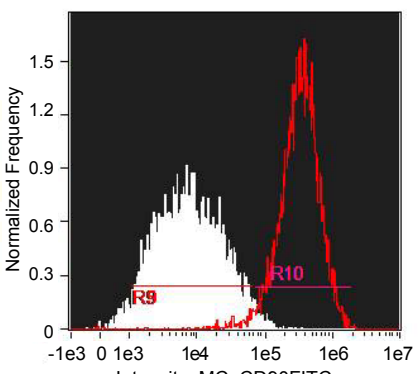

Intensity_MC_CD90FITC
All

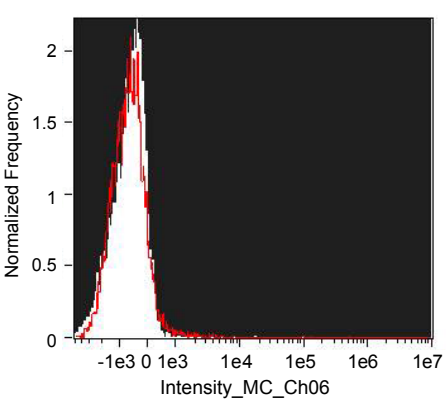

Intensity_MC_CD90 FITC

\begin{tabular}{|l|l|l|}
\hline Population & Count $\%$ Gated & Median \\
\hline
\end{tabular}

\begin{tabular}{|l|l|l|l|}
\hline All & 10000 & 100 & 344664.72 \\
\hline R9 & 208 & 2.08 & 43254.1 \\
\hline R10 & 9742 & 97.4 & 350678.82 \\
\hline
\end{tabular}

Figure 4: Representative picture of phenotypic characterization of MSCs derived from various dental sources.

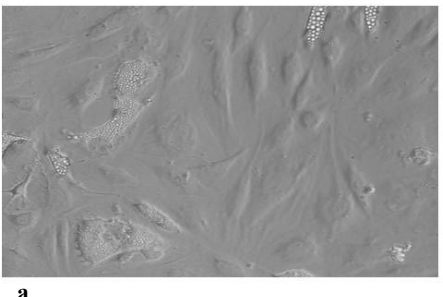

a

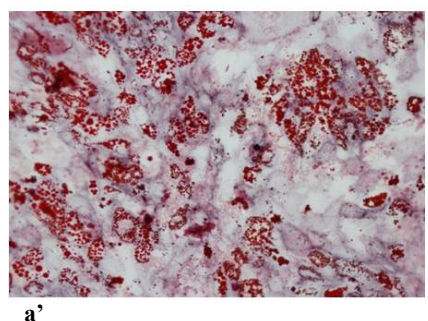

a'

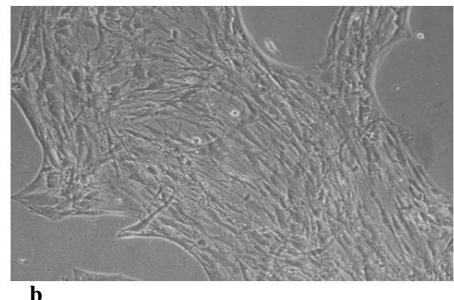

b
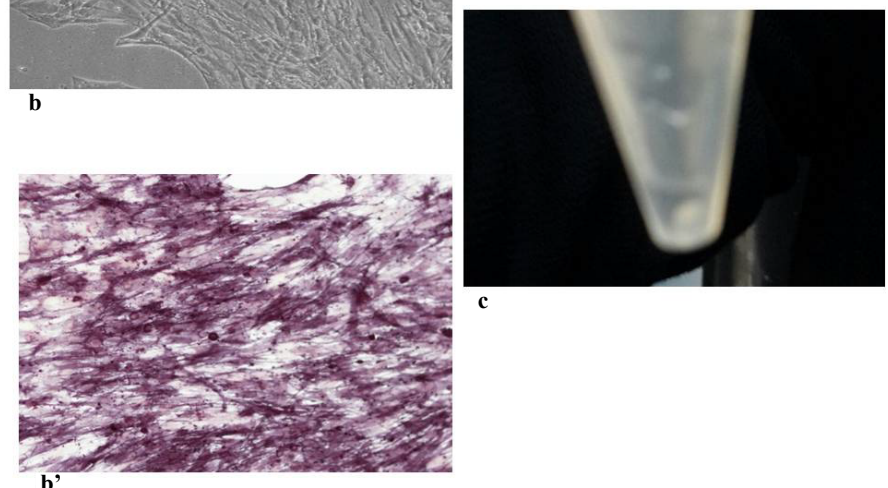

c
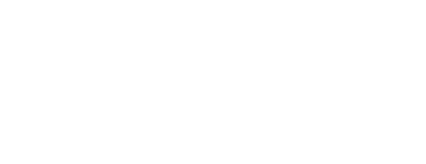

Figure 5: Representative picture of Adipogenic (a and a'), Osteogenic (b and b') and chondrogenic (c) characterization of second-to-third MSCs derived from various dental sources.

maturity range is between $10-12$ years, because of which we were not able to observe any AP.

Amount of Periodontal Ligament (PDL) and Gingiva are not age-dependent [11]. This may owe to their functionality vis-a-vis maintaining the integrity of the tooth. However, in our study in older age group the number of MSCs isolated were very less.

\section{References}

1. Park YJ, Cha S, Park YS (2016) Regenerative Applications Using Tooth 
Citation: Singh N, Verma UP, Chowdhury R, Mishra A, Sahu DK, et al. (2016) Enumeration and Characterization of Mesenchymal Stem Cells from Age-dependent Human Dental Tissue. J Stem Cell Res Ther 6: 359. doi: 10.4172/2157-7633.1000359

Page 5 of 5

Derived Stem Cells in Other Than Tooth Regeneration: A Literature Review. Stem Cells Int 2016: 9305986. [Pubmed]

2. Huang GT, Gronthos S, Shi S (2009) Mesenchymal stem cells derived from dental tissues vs. those from other sources: their biology and role in regenerative medicine. J Dent Res 88: 792-806. [Pubmed]

3. Han J, Menicanin D, Gronthos S, Bartold PM (2014) Stem cells, tissue engineering and periodontal regeneration. Aust Dent J 59: 117-130. [Pubmed]

4. Kawaguchi H, Hirachi A, Hasegawa N, Iwata T, Hamaguchi $H$, et al. (2004) Enhancement of periodontal tissue regeneration by transplantation of bone marrow mesenchymal stem cells. J Periodontol 75: 1281-1287. [Pubmed]

5. Yen $\mathrm{AH}$, Yelick PC (2011) Dental tissue regeneration - a mini review. Gerontology 57: 85-94. [Pubmed]

6. Marshall-Day CD, Stephens RG, Quigley LF (1995) Periodontal disease: prevalence and incidence. J Periodontol 26: 185-203.
7. Loe H, Brown LJ (1991) Early onset periodontitis in the United States of America. J Periodontol 62: 608-616. [Pubmed]

8. Dominici M, Le Blanc K, Mueller I, Slaper-Cortenbach I, Marini F, et al. (2006) Minimal criteria for defining multipotent mesenchymal stromal cells. The International Society for Cellular Therapy position statement. Cytotherapy 8: 315-317. [Pubmed]

9. Kobolak J, Dinnyes A, Memic A, Khademhosseini A, Mobasheri A (2016) Mesenchymal stem cells: Identification, phenotypic characterization, biological properties and potential for regenerative medicine through biomaterial microengineering of their niche. Methods 99: 62-68. [Pubmed]

10. Satheeshkumar PS, Mohan MP, Saji S, Sadanandan S, George G (2013) Idiopathic dental pulp calcifications in a tertiary care setting in South India. Conserv Dent 16: 50-55. [Pubmed]

11. Thesleff I, Vaahtokri A, Partanen AM (1995) Regulation of organogenesis. Common molecular mechanisms regulating the development of teeth and other organs. Int J Dev Biol 39: 35-50. [Pubmed] 